\title{
國有種牡馬體格體型の役種別, 優劣別調查
}

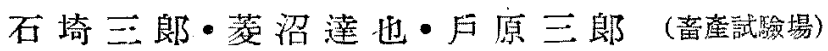

A biometric investigation on forms of stallions in Japan.

Saburo Ishlzak1, Tatsuya Hishinuma \& Saburo Tobara

(Imperial Zootechnical Experiment Station, Nasu)

\section{I 緒 言}

我分國の馬匹は馬政計畫澍犃以來一定方針の下 外國改良種索以て改良索行ひ，此の 40 䚢作間 長足の進步を逐げ，在來の矮馬は殆んゼ乞の影 洺し, 各種用途汇對して體格能力共に著しき向

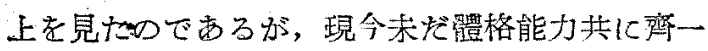
した日本固有つ品種として認为得る范に至つてる 广い。

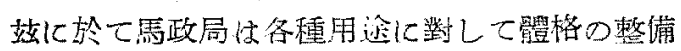

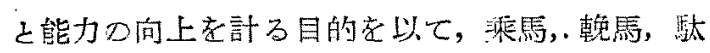

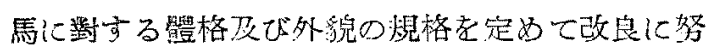
カしつ」かるのである。

件し馬政局に於て定めたる規格制定に位々各種 用途焉の分類依經驗を主已する相馬法に依つたの であつて,科學的根據!と泛しい感み宗し々しない。 仍つて本調查は日本國有種牡馬 體格體型の現狀を明らかにする 之共沉, 此の䫀格制定に位る分 類の筫態考明確ならししる目的 で行つたので西る。

\section{II材料及ひ調查方法}

材料は東北地方(枋木種馬所 老含む）北海道所在の各種馬場

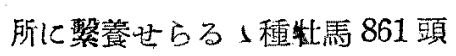
より成り, 何れる成馬でする。

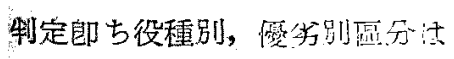
馬政局に於て行代る山種牳馬?

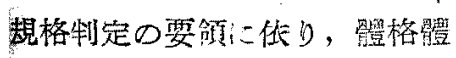
型の觀點の灭上り之老行つた。

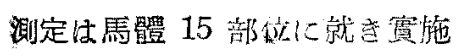

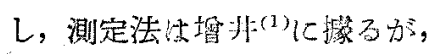

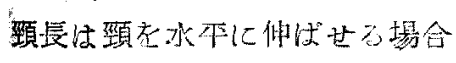

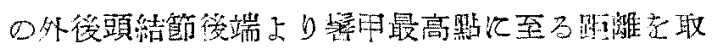
b, Schmalty ${ }^{(2)}$ ：に據つた。

制定及び測定何何孔昭和 16 年 12 月より同

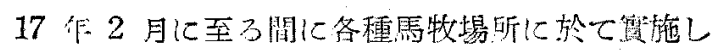
たものである。

\section{III 各部位測定犆並に體高指數}

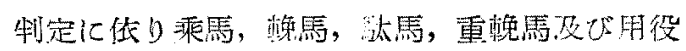

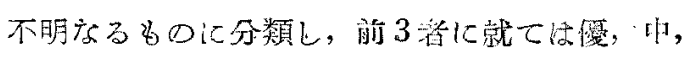

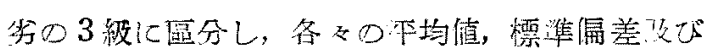

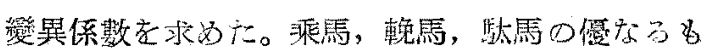

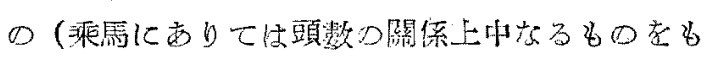

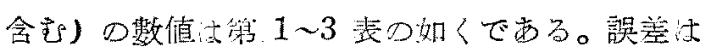

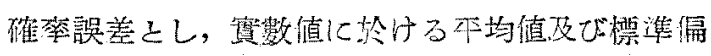

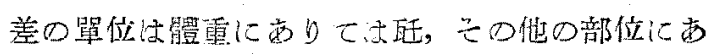
りては糧でする。

第 1 表 乘照の愿及び中なるるの>测定㥀

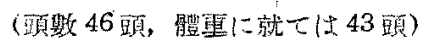

\begin{tabular}{|c|c|c|c|c|c|c|}
\hline \multirow{2}{*}{ 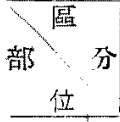 } & 理 & \multicolumn{2}{|l|}{ 值 } & 體 & \multicolumn{2}{|c|}{ 数 } \\
\hline & 平均值 & 慓準侀差 & 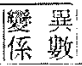 & 平均 值 & 栖準僱美 & 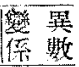 \\
\hline 高 & $156.5 \pm 0.25$ & $2.56 \pm 0.180$ & 1.6 & $\longrightarrow$ & & - \\
\hline 長 & $160.0 \pm 0.34$ & $3.45 \pm 0.242$ & 2.2 & $102.2 \pm 0.22$ & $2.25 \pm 0.158$ & 2.2 \\
\hline 樑 & $73.8 \pm 0.17$ & $1.66 \pm 0.117$ & 2.2 & 47.3 上0.09 & $0.88 \pm 0.061$ & 1.9 \\
\hline 長 & $82.5 \pm 0.22$ & $2.18 \pm 0.153$ & 2.6 & $52.8 \pm 0.09$ & $0.88 \pm 0.061$ & 1.7 \\
\hline 瑟 & $59.9 \pm 0.17$ & $1.67 \pm 0.123$ & 2.8 & $38.2 \pm 0.11$ & $=0.075$ & 2.7 \\
\hline 㹂 & $98.1 \pm 0.38$ & \pm 0.270 & 3.8 & $62.7 \pm 0.23$ & 2.30 & 3.7 \\
\hline 图 & $188.3 \pm 0.44$ & \pm 0.312 & 2.4 & $120.2 \pm 0.26$ & 2.64 & 2.2 \\
\hline 管 & $20.8 \pm 0.07$ & $0.67 \pm 0.047$ & 3.2 & $13.3 \pm 0.04$ & $=0.029$ & 3.1 \\
\hline 墙 & $44.4 \pm 0.12$ & $1.24 \pm 0.087$ & 2.8 & $2 \varepsilon .3 \pm 0.08$ & $0.82 \pm 0 \cdot(\mathbf{5} 8$ & 2.9 \\
\hline 幅 & $45.0 \pm 0.18$ & $1.76 \pm 0.124$ & 3.9 & $28.8 \pm 0.12$ & $1.16 \pm 0.082$ & 4.0 \\
\hline 幅 & $55.8 \pm 0.15$ & $1.49 \pm 0.105$ & 2.7 & $35.8 \pm 0.09$ & $0.92 \pm 0.065$ & 2.6 \\
\hline 輻 & $53.8 \pm 0.13$ & $1.26 \pm 0.089$ & 2.3 & $34.4 \pm 0.09$ & $0.91 \pm 0.064$ & 2.6 \\
\hline 尻 朢 & $54.9 \pm 0.17$ & $1.74 \pm 0.123$ & 3.2 & $35.1 \pm 0.11$ & $1.11 \pm 0.078$ & 3.2 \\
\hline 前槂幅 & $10.8 \pm 0.04$ & $0.37 \pm 0.026$ & 3.4 & $6.8 \pm 0.02$ & $0.21 \pm 0.015$ & 3.1 \\
\hline 䠣 重 & $582.3 \pm 3.30$ & $32.05 \pm 2.331$ & 5.5 & $370.5 \pm 1.87$ & $18.19 \pm 1.323$ & 4.9 \\
\hline
\end{tabular}




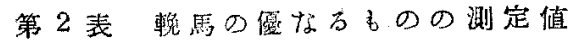
(頭數 53 頭，體重に就ては 42 頭)

\begin{tabular}{|c|c|c|c|c|c|c|}
\hline 區 & 實 & 徝 & & 體 & 指 & \\
\hline & 事均 值 & 標㰾编差 & 侪 & 平 均 & & 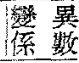 \\
\hline 高 & $156.8 \pm 0.35$ & $3.73 \pm 0.245$ & 2.4 & - & $-\ldots$ & - \\
\hline 琹 & $165.6 \pm 0.42$ & $4.57 \pm 0.292$ & 2.2 & $105.6 \pm 0.28$ & $2.98 \pm 0.195$ & 2.8 \\
\hline 深 & $75.2 \pm 0.26$ & $2.85 \pm 0.187$ & 3.2 & $48.1 \pm 0.12$ & $1.31 \pm 0.086$ & 2.7 \\
\hline 喜 & $81.3 \pm 0.26$ & $2.76 \pm 0.181$ & 3.4 & $51.9 \pm 0.12$ & $1.31 \pm 0.086$ & 2.5 \\
\hline 蜸 & $60.8^{\circ} \pm 0: 19$ & $2.09 \pm 0.137$ & 3.4 & $33.9 \pm 0.11$ & $1.13 \pm 0.074$ & 2.9 \\
\hline 頸 & $99.0 \pm 0.34$ & $3.70 \pm 0.243$ & 3.7 & $63.1 \pm 0.20$ & $2.11 \pm 0.138$ & 3.3 \\
\hline 胸 & $193.4 \pm 0.50$ & $5.37 \pm 0.351$ & $2 \cdot 8$ & $123.1 \pm 0.28$ & $3.01 \pm 0.197$ & 2.4 \\
\hline 管 & $22.2 \pm 0.14$ & $1.54 \pm 0.101$ & 7.0 & $14.1 \pm 0.06$ & $0.60 \pm 0.039$ & 4.2 \\
\hline 堙 & $46.9 \pm 0.19$ & $1.99 \pm 0 \cdot 130$ & 4.3 & $29.9 \pm 0.10$ & $1.03 \pm 0.067$ & 3.5 \\
\hline 愊 & $47.4 \pm 0.23$ & $2.45 \pm 0.161$ & 5.2 & $s 0.2 \pm 0.15$ & $1.60 \pm 0.105$ & 5.3 \\
\hline 幅 & $58.0 \pm 0.16$ & $1.72 \pm 0.113$ & 3.0 & $37.0 \pm 0.10$ & $1.10 \pm 0.072$ & 3.0 \\
\hline 幅 & $56.9 \pm 0.14$ & $1.51 \pm 0.098$ & 2.7 & $\varepsilon 6.4 . \pm 0.11$ & $1.14 \pm 0.075$ & 3.1 \\
\hline 尻訾 & $57.0 \pm 0.19$ & $2.00 \pm 0.131$ & 3.5 & $36.7 \pm 0.13$ & $1.41 \pm 0.092$ & 3.8 \\
\hline 前朣茴 & $11.4 \pm 0.06$ & $0.66 \pm 0.043$ & 5.6 & $7.2 \pm 0.04$ & $0.41 \pm 0.027$ & 5.7 \\
\hline 體 重 & $\varepsilon 36.2 \pm 3.88$ & $37.24 \pm 2.740$ & 5.6 & $402.9 \pm 2.24$ & $21.56 \pm 1.5 \varepsilon 6$ & 5.4 \\
\hline
\end{tabular}

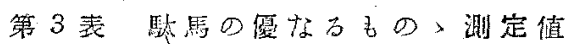

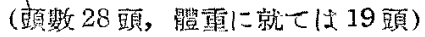

\begin{tabular}{|c|c|c|c|c|c|c|}
\hline & 筫 & 測 & & 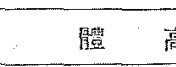 & 指 & \\
\hline 位 & 平均值 & 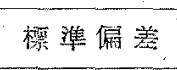 & 攣累斯 & 平 均 值 & 睏準偏差 & 噟 寨 \\
\hline 體 高 & $151.9 \pm 0.34$ & $2.67 \pm 0.241$ & 1.8 & - & - & - \\
\hline 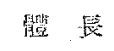 & $158.8 \pm 0.56$ & $4.42 \pm 0.399$ & 2.8 & $104.7 \pm 0.33$ & $2.61 \pm 0.235$ & 2.5 \\
\hline 㩆 & $72.8 \pm 0.29$ & $2.29 \pm 0.206$ & 3.1 & $48.0 \pm 0.16$ & $1.23 \pm 0.111$ & 2.6 \\
\hline 長 & $78.9 \pm 0.28$ & $2.21 \pm 0.199$ & 2.8 & $51.9 \pm 0.16$ & $1.22 \pm 0.109$ & 2.3 \\
\hline 堎 & $50.0 \pm 0.26$ & $2.03 \pm 0.183$ & 3.4 & $39.0 \pm 0.14$ & $1.09 \pm 0.098$ & 2.8 \\
\hline 彭 & $94.8 \pm 0.44$ & $3.45 \pm 0.312$ & 3.7 & $62.2 \pm 0.28$ & $2.1_{6} \pm 0.198$ & 3.5 \\
\hline 嵲 & $187.6 \pm 0.55$ & $4.28 \pm 0.386$ & 2.3 & $123.7 \pm 0.30$ & $2.36 \pm 0.212$ & 1.9 \\
\hline 䟧 & $21.0 \pm 0.09$ & $0.69 \pm 0.062$ & 3.3 & $13.8 \pm 0.05$ & $0.38 \pm 0.034$ & 2.7 \\
\hline 曆 & $44.5 \pm 0.19$ & $1.47 \pm 0.133$ & 3.3 & $29.4 \pm 0.13$ & $0.99 \pm 0.089$ & 3.4 \\
\hline 悯 & $44.8 \pm 0.27$ & $2.14 \pm 0.193$ & 4.8 & $29.5 \pm 0.19$ & $1.48 \pm 0.133$ & 5.0 \\
\hline 幅 & $55.5 \pm 0.20$ & $1.61 \pm 0.145$ & 2.9 & $36.7 \pm 0.13$ & $1.02 \pm 0.082$ & 2.8 \\
\hline 尻 & $54.2 \pm 0.16$ & $1.26 \pm 0.113$ & 2.3 & $35.8 \pm 0.09$ & $0.74 \pm 0.067$ & 2.1 \\
\hline 觉 步 & $55.2 \pm 0.22$ & $1.69 \pm 0.152$ & 3.1 & $36.4 \pm 0.14$ & $1.09 \pm 0.098$ & 3.0 \\
\hline 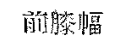 & $10.7 \pm 0.06$ & $0.43 \pm 0.038$ & 4.0 & $7.1 \pm 0.03$ & $0.25 \pm 0.023$ & 3.5 \\
\hline 䶆 重 & $588.2 \pm 4.49$ & $29.03 \pm 3.177$ & 4.9 & $387.9 \pm 2.97$ & $19.22 \pm 2.103$ & 4.9 \\
\hline
\end{tabular}

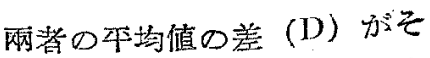
の標蕉誤差 $(\mathrm{m}) \odot 3$ 倍以上 にして差の有意なる索認得る は, 胸幅, 腰幅, 层幅, 丹長, 胸圍, 管園, 胿圍, 胸深, 體

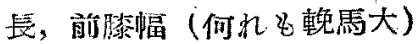
○各部位である。尻幅の如 平均値の差は約 3 堐, $\mathrm{D} / \mathrm{m}$ は 11 を示す。

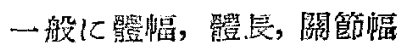
胸管圍, 體重に於て差を示す

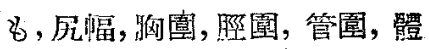
重等之刀測定敒笳肉量つ參與 する部位に於て特に大なる差 あるは乘哥已輓馬の筇淩量の

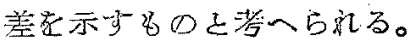

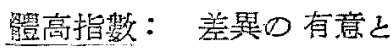

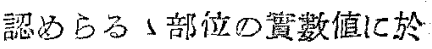
ける㙋合之異る纯肢長它增し た點である。 D/m の大なる bD1中完愊の 9.3 , 前管圍,

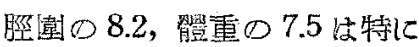
著しい。郎古䠦幅, 體長, 關 節愊, 蕧呀の發達, 筋肉及び 骨量就美加認内られる。

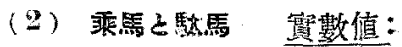
頸長，體高，渎長の各部位に 於て乘哥大にして，後 2 者は 特しその差著しい。體幅，關 篔愊, 胸管圍, 體重等に差覃 の有意性を認め得なかつた。

體高指數：此の比较は實 謷值に放ける㙷合上煩る異り

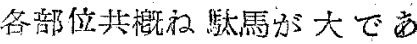
る。差異口有琶已認めらる、《要幅, 尼幅, 层長,

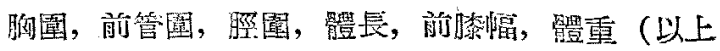

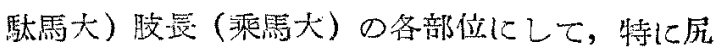
幅, 胸園, 前管園, 前膝幅の客部始に於て之の美 著しい。

毁ち體幅, 體长, 關第幅, 後軀の發達, 觔肉及

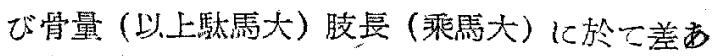


り，此の點㲀馬仗輓馬に類似するも耕馬さの差異 の程度は輓第に於ける程著しくはない。

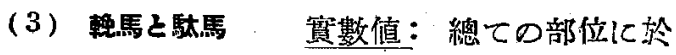
て輓馬が大である。差異の著しき忙腰幅, 尼幅, 胸圍, 頸長, 脛園, 體高, 體長, 前滕幅, 體重の 各部位にして， D/m の最大なるは尻幅の 8.7 で 更る。

輓馬は一般に歌馬より各部位共に大なりを言ひ 得る。

體高指數：實數値に於放る場合と異り差異の 有意性を認め得るは前管圍の外にして他は認め得 ず, 此の事實より見る時は現你國有種馬體型に於 て輓駄馬間に著しを差異なく，寧ろ輓馬の小なる ものを駄馬とせるに過ざるるの多さの感方古 3。

（4）用役不明のあのと各推種馬䁈數值：用

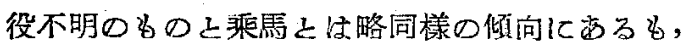
䁏幅; 版園, 眴深, 體重 (乘馬大) の各部位に於 て差の有意なるを認め得る。用役不明のるの之端

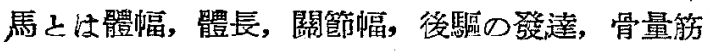
肉量に關係する各部位に於て輓馬著しく大にし

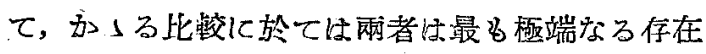
である。用役不明のるのと駘馬とは肢長に於て前 者長く解肉量關係する部位等し於て後者大です る。

體高指數：明役不明のものは派馬とは腰幅, 胸 睹, 體重の外羑異の有意性を認め得ない。用役不 明のもの工輓馬乞に各部位に差の有意なる索認め 得, その著しをは胸幅, 䁏幅, 层幅, 尼長, 胸圍, 前管圍, 脛圍, 胸深, 體長, 前膌幅, 體重 (以上 輓馬大) 䑩長（用役不眗のもの大）の各部位にし $\tau$, 尼幅, 胸圍, 前管圍, 脛圍, 體重の如音 $\mathrm{D} / \mathrm{m}$ は 10.0 以上を示す。用役不明のもの之䭾馬之も 概社之に準する結果を示す。

\section{口. 各役種間の種族類似係數}

各役種體格

體型の差を總體的に明らかならしむる目的字以て

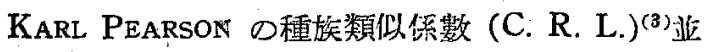
ic MORANT の還元せられたる種族類似係數 (R. C. R. L.) $)^{(3)}$ を算出した。比較の對象こせるは體 長, 胸幅, 胸深, 胸園, 管圍, 前膝幅, 腰幅, 层 幅, 尼長, 脛圍, 肢長, 頭長, 莖䍗, 體重, 尼高,

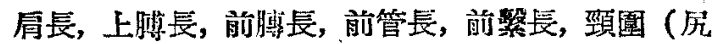
高以下の各部位はその數值を本文に於て揭げざる ๖゙，測定を賽施したるものの２1 部位でする。

種族颗似數 (C. R. L.)

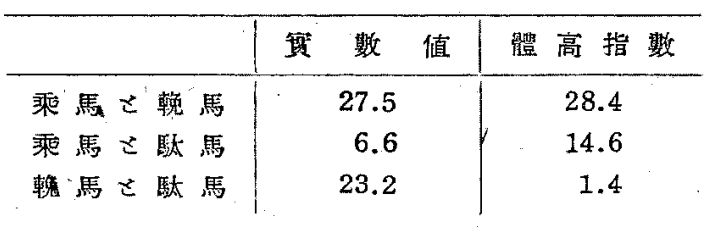

罯元さられたる程族類似係数

(R. C. R. L.)

\begin{tabular}{|c|c|c|}
\hline & 筫 政 傎 & 體 高指 數 \\
\hline 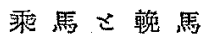 & 56.3 & 58.1 \\
\hline 乘再こ贆，臨 & 19.2 & 42.4 \\
\hline 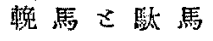 & 63.8 & 3.9 \\
\hline
\end{tabular}

種族類似係數：乘婜之輓馬之は實數值に於て 当體高指數に於ても爾諸の租異る事明白で西る。 乘馬と䭾馬は前者程甚しからざるる差異を示す。，

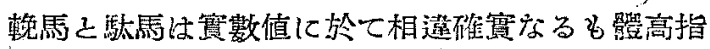
数に於ては差異の有船を明らかにしない。

還元せられたる種族類似係數：溗馬之輓馬心 實數値; 體高指數共に相當の差異を示す。乘馬と 䭾馬は䁈數倌に於てはその相違は著しからす，兩 者の近似性を示ず, 體高指數に於ては可成りの 差累が認めらる。輓馬と駄馬は實數値に於てはそ の差罴しき为體高指數に於てはその差を明方かに しない。

入. 關俰偏差曲線に依るむの MoLLISON の

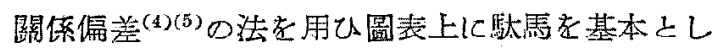
乙維軸に $\mathrm{M}, \mathrm{M}+\boldsymbol{\sigma}, \mathrm{M}-\boldsymbol{\sigma}$, 取 $b$, 輓馬數值 の駄馬數值を超過する程度に依り橫䩗に馬體各部 位を排列し，輡歌馬及び用役不明のひの今平均值 の偏差曲線老記入するに附圖第 1 2 ○如くあだ る。

實數值：輓馬平均值は大部分の 部位に於て跃 馬平均值より大なるも, 特に伲偪, 體高, 體重, 管園, 脛圍, 䣓長, 前滕幅, 腰幅の體量體幅に最 女關係ある重要部位に於て著しい。乘馬平均值は

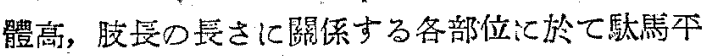
均值よりこの $\sigma$ 以上大にして, 偏差曲線々振幅 大なるも大體て於て輓馬曲線乙歌馬の線の間に含 


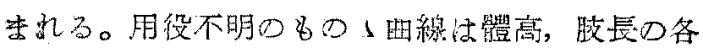

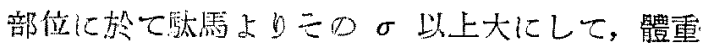

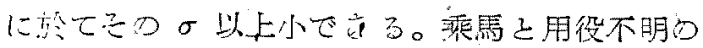

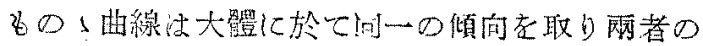

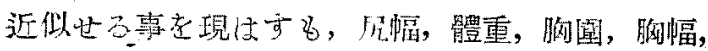

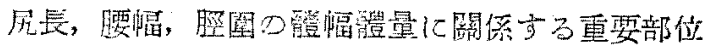
に於て用役不明のもの劣り，河省の差の特徵定示 ?े

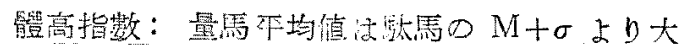

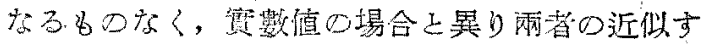

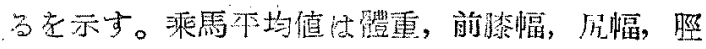

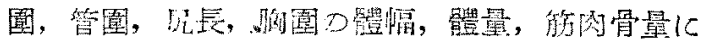
關係する部位に然て新琵つ $\mathrm{M}-\sigma$ より小でする。

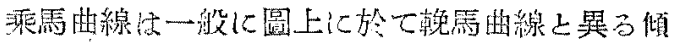

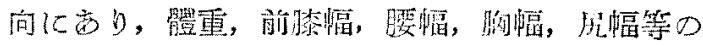

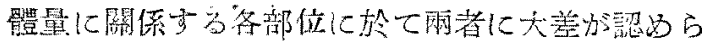

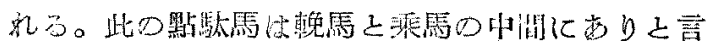

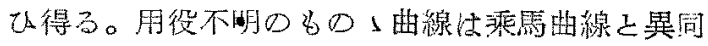

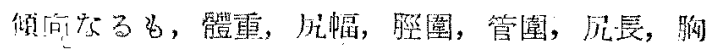

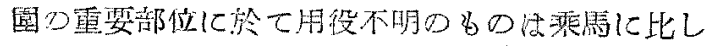
て小である。

\section{$\mathrm{V}$ 儚劣別比較}

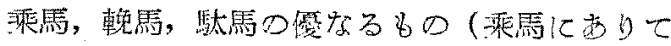

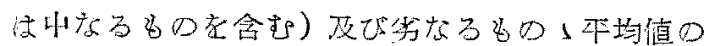

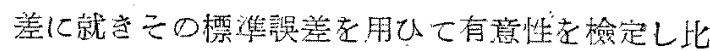
較衣行つた。

\section{(1) 乘 馬 筫数值: $\mathrm{D} / \mathrm{m}$ 加 3.0}

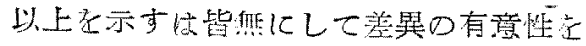

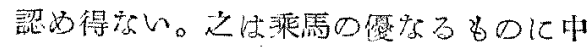

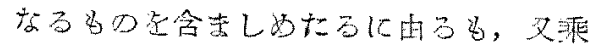

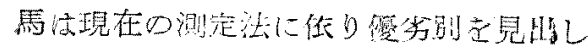

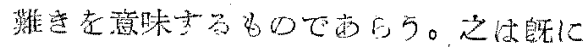

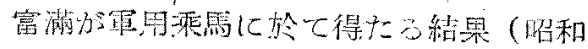

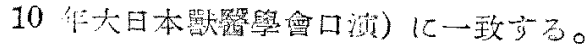

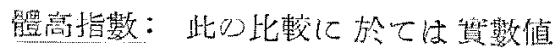

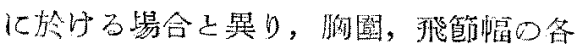

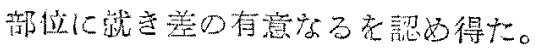

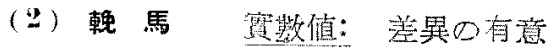

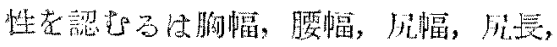

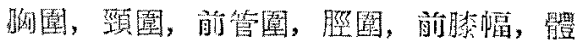

重の各部位である。その差著しく $\mathrm{D} / \mathrm{m} の 5.0$ 以 上を示すは胸腷, 腰嵒, 尼愊, 胸圍, 脛園, 體重 の各部位にして，居楅の 9.0, 胸圍の7.0は特に

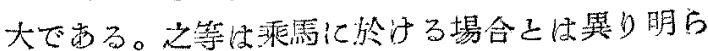

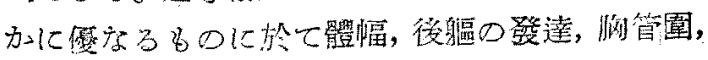

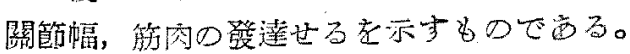

體高指毁：差異の有意性を認め得る部位は實 數值に於ける場合已略同一なるも異る仗胸深(優 なるもの大）胶最（劣なるるの大）を增した點で

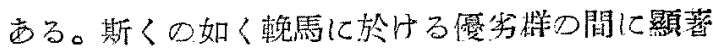
なる差巽定示し，體幅，胸園口如體量に關係す

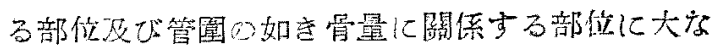

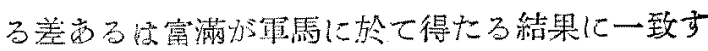
る。

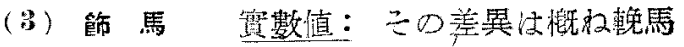

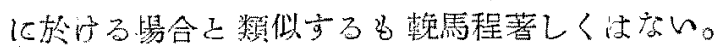

體敦指数：實数值に於り゙る埸合己略一致する。

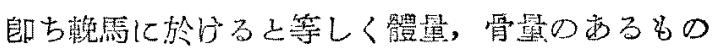

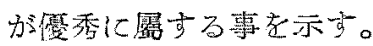

\section{VI 總括}

（1）國有種牞需 861 頭!就羔馬體 15 部位の

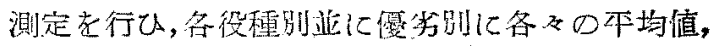

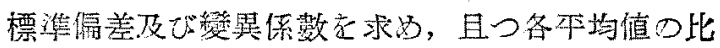

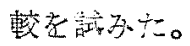

（2）役種別比較は次の如くで㐫る。

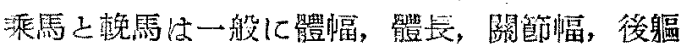

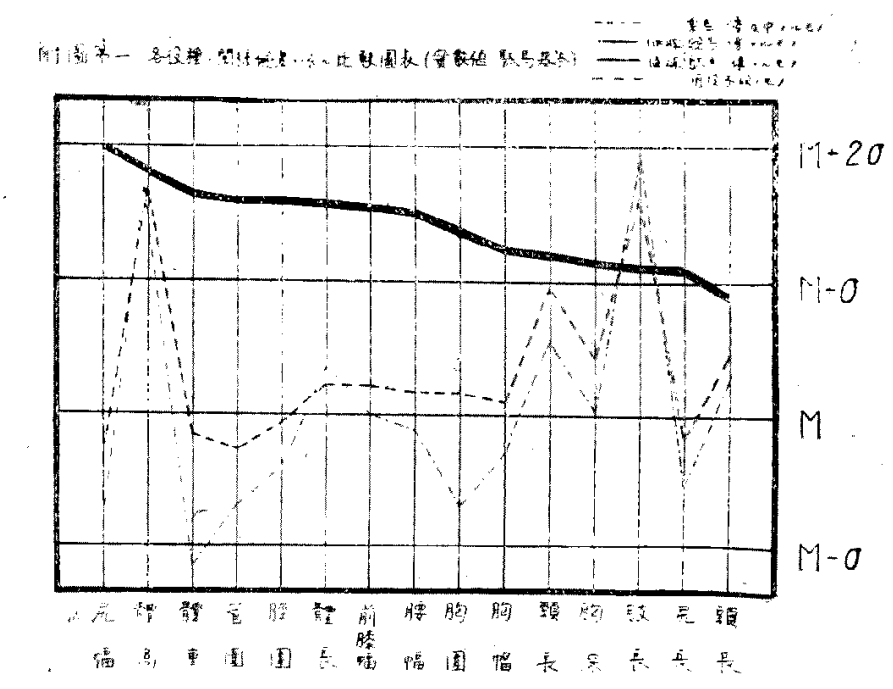




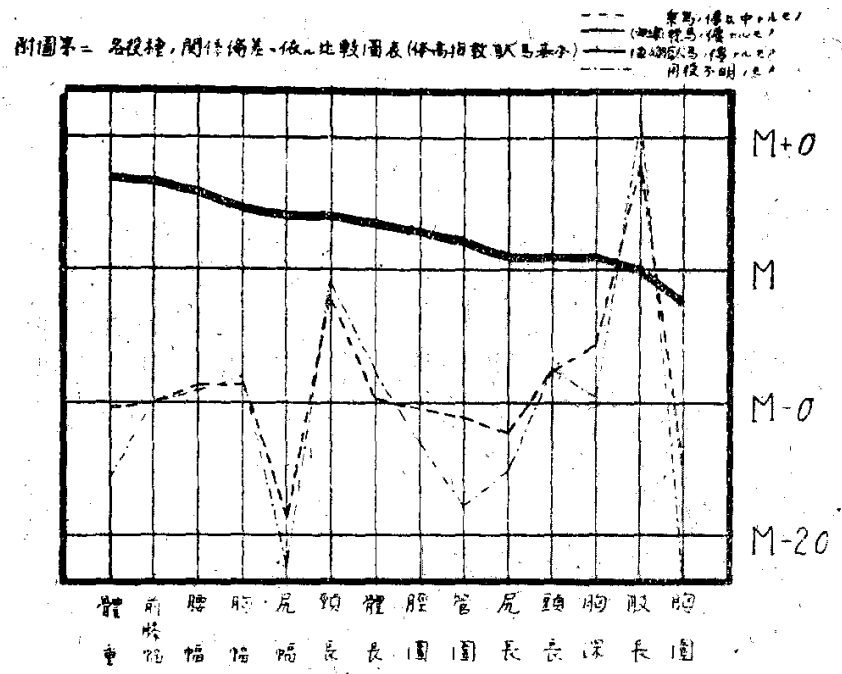

倚各役種間の種族類似係㛒並に還元せ られだる種族類似係數を算出乙，又閵係

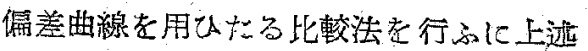
せる上路同㥞心絬果字得た。

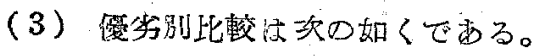

乘霝は测定に依り他の役種に比しその

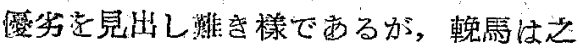
に辰し優劣心美異は體愊，後軀の發達，

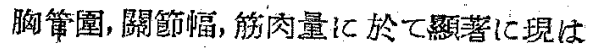

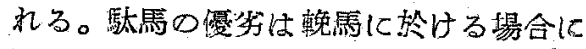
準するもとの差は輓馬程著しくはない。

終りに御根篤なる御指導を賜りたる當

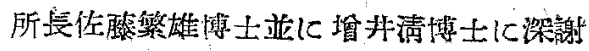
し，本調查賽施當り烧格刵定に拹力せら

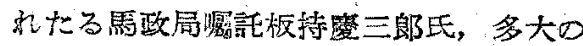

の發達,一箁肉滑量に於て輓馬が著しく大で西る。 乘馬之歌馬之は一般に體高, 肢の長さ等に於て涞 馬優り, 體幅, 體長, 關笁愊, 胸管園, 體重等の 部位に於ては，實數值にては差異の有意性索認め

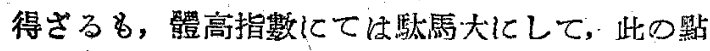

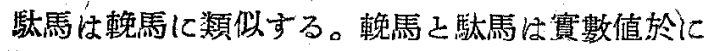
て輓馬は一般て熙馬より大なるる，體高指數に於 ては管圍の外差異の有意性を認め得ず, 現在の國 有種出馬に於ては雨者の體型の間に明確なる差異 なをものと認めらる。

援助亡便宜を與人られたる各種馬牧場所長，職員 各位に感謝の意を夌する。

\section{主 要 文 跃}

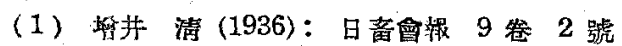

(2) Schmalty, R. (1922): Messungen und Wägungen am Pferd. Berlin.

(3) Bonjin, G. von. (1931): Anthrop. Anzeiger. Jahrg. 7

(4) Moluson, Th. (1908): Zeitsth. f. Morphologie u. Anthropologie. Bd. II

（5）上田常吉, 高福功 (1934)：解剖雜 7 忩 6 號

\section{牛の黄體除去水關する研究}

渡邊守松，常包正; 势四孝一即

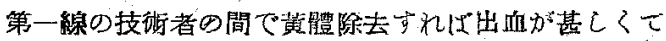
有害であるさか，又除去して發情が明瞭に二ないてか 或に又發情があつても第一间の㭙に種付して丰受胎しな

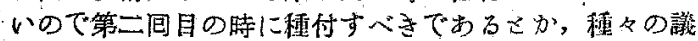

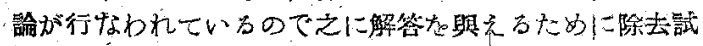

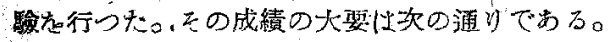

昭和 21 年 4 月加少 10 月迄に取报つた患䈏 74 䫒の

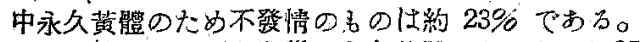

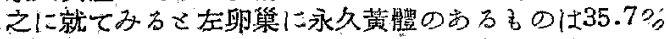

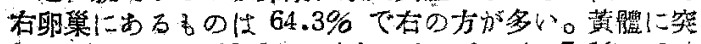
起のあるるのは 93.9\%，突起のないるのは7.1\%で殆 突起がある。二の黄體起除去して后, 3 日以內に發情

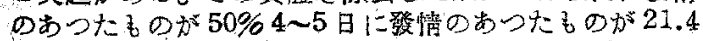

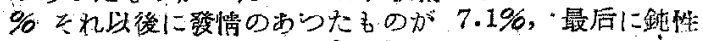
發情に終つた手のが 21.4\%、である。

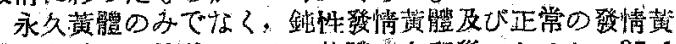

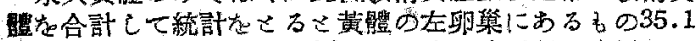

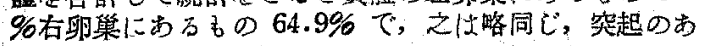

\section{要 旨}

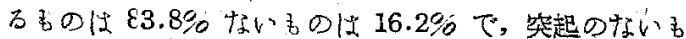

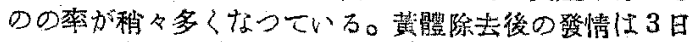

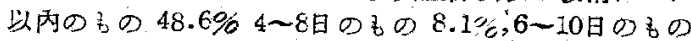

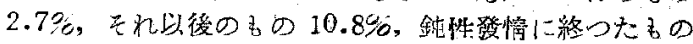
$24.3 \%$ であつて, 發情のおくれるるのが多くなつたのは

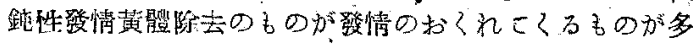

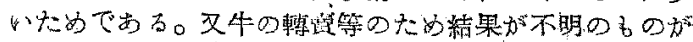

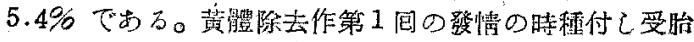

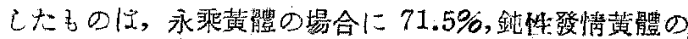

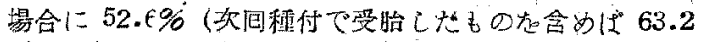

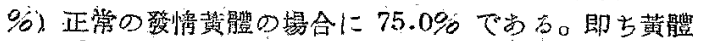

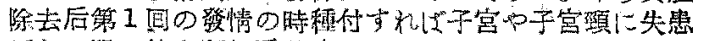
がない限り約七制位受腊声ら。

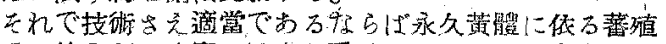

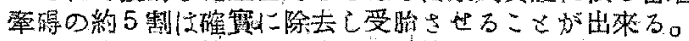

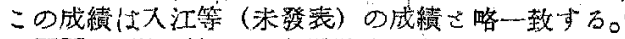

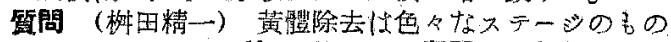
についてなとたか，(答) 然り (侗問) 永久黄嚂には

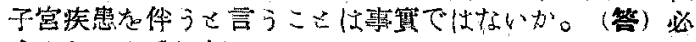
すてもきうではない。 